\title{
Peculiarities of dividend policy of Russian companies in post-crisis period
}

\author{
Lukasevich Igor \\ Financial University under the Government of the RF \\ Moscow, Russian Federation \\ lukas1963@yandex.ru
}

\author{
Sukhorukova Daria \\ Financial University under the Government of the RF \\ Moscow, Russian Federation \\ DVSuhorukova@fa.ru
}

\begin{abstract}
The article considers main theoretical and practical aspects of the dividend policy in Russian companies in the post-crisis period as well as the peculiarities of its implementation in modern conditions. The research is based on the analysis of more than 1000 Russian companies for the period of 2009-2015, whose shares are traded on the MICEX. The article highlights the key factors that influence the dividend policy in Russia and have given a description of the main stages of its development.
\end{abstract}

Keywords - dividend policy; dividend analysis; post-crisis period component

\section{INTRODUCTION}

The maximization of business value and its value for owners is the main goal of management. Therefore, it is not surprising that financial relationships with owners, whether it is a sole proprietor or millions of shareholders of a large corporation, have a significant impact on the development strategy of any firm. In economic practice, the adoption of management decisions in this area is carried out within the framework of the dividend policy.

Theoretical aspects of dividend policy are quite various and complex; however, the following questions are considered as the main ones: do the decisions on payments to owners affect the firm's value and what should their optimal value be? Despite numerous studies in this field abroad, these issues remain the subject of debate among scientists and practitioners $[2,3,4,5,6,8]$.

This article will consider the main theoretical and practical aspects of the dividend policy of Russian companies, as well as the features of its implementation in modern conditions.

Less than three decades ago, the absence of dividend policy was quite typical for Russian enterprises. A few cases of dividends payment did not play a special role because of the insignificance of the announced amounts. Since 2001, the situation has begun to change dramatically, when many large corporations that were interested in raising capital from financial markets also improved their reputation and the quality of management and forming a positive image in the eyes of foreign investors began to pay dividends on a regular basis. Later in the charters and corporate codes of the leading domestic companies, a paragraph or a separate document appeared that was revealing the content of their dividend policy.

Studies have shown that during the evolution of the dividend policy of domestic companies, there can be distinguished three periods (stages): "birth" (1994-1998); "formation" (2001 - 2007); "maturity" (2009 - up to the present).

It is not difficult to see that the given periods coincide with the financial crises of recent decades.

The peculiarities of the dividend policy of Russian companies in the first two stages were reflected in a number of publications and were also considered in certain papers [9].

\section{RESULTS}

The analysis shows that the specific features that are characteristic of the dividend policy of domestic companies can be grouped according to two directions that are closely interrelated:

- exogenous, determined by macroeconomic and foreign policy conditions as well as institutional factors;

- endogenous, caused by internal factors and the microenvironment of the activities of the companies themselves.

The most significant factors of the first group include:

- uneven growth and disproportions in the development of separate sectors of the economy;

- the composition of owners that is based on the specifics of the mechanism of privatization of the Russian enterprises, as a result of which a significant proportion of their shares belongs to the state, a small number of people or management;

- economic sanctions of Western countries, which significantly restricted the access of the Russian companies to the world capital markets;

- transparency and clarity of legislation in this sphere.

The current stage of the development of the Russian economy is characterized by considerable sectorial disparities. In addition, the most intensive development in recent years has occurred in the oil and gas sector, metallurgy and telecommunications. The uneven development of various 
industries and sectors affects both the revenues received by enterprises and their distribution. The table below shows the dividend yield of the MICEX sectorial stock indices in 20152016.

TABLE I. Dividend yield of sectorial indices of Russian Federation ${ }^{\mathrm{a}}$

\begin{tabular}{|l|c|c|c|}
\hline \multicolumn{1}{|c|}{ Stock/Indexes } & $\begin{array}{c}\text { Stock } \\
\text { payment } \\
(\mathbf{r u b})\end{array}$ & $\begin{array}{c}\text { Payment } \\
\text { yield }\end{array}$ & $\begin{array}{c}\text { Capitalisatio } \\
\mathbf{n} \\
(\mathbf{m l n} \mathbf{\$}, \mathbf{U S})\end{array}$ \\
\hline MICEX index & 142.94 & $5.71 \%$ & 522855.12 \\
\hline MICEX index Telecoms & 23.91 & $9.49 \%$ & 18626.08 \\
\hline MICEX index Metals & 270.84 & $6.47 \%$ & 99864.48 \\
\hline MICEX index Consumer sector & 74.21 & $5.13 \%$ & 27820.95 \\
\hline MICEX index Oil and Gas & 327.32 & $4.98 \%$ & 247349.55 \\
\hline MICEX index Chemicals & 89.98 & $4.86 \%$ & 20080.08 \\
\hline MICEX index Utilities & 0.0852 & $3.73 \%$ & 31136.25 \\
\hline MICEX index Finances & 3.08 & $2.79 \%$ & 76512.48 \\
\hline MICEX index Machine industry & 0 & $0 \%$ & 2477.04 \\
\hline
\end{tabular}

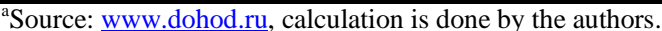

The table above shows that the largest dividend yield is demonstrated by the companies of the telecommunications sector. The payments of high and stable dividends by telecom companies are connected with both the intensive growth of the industry in recent years and the level of corporate governance that practically meets the world standards. This dividend policy is also explained by the composition of the shareholders of the companies in this sector, including many institutional foreign investors, and by the circulation of a number of shares in the form of depositary receipts on international stock exchanges - NYSE, LSE, etc.

In terms of payments, oil and gas and metallurgical companies are traditionally the leaders, as together they have more than $65 \%$ in the Russian stock indices. A significant share of dividend payments (60.9\% and $14 \%$, respectively) in these sectors is based on both high incomes and significant need for additional investments. The desire to attract external investors, including somebody from abroad, forces the companies of these sectors to implement a transparent dividend policy.

At the same time, machine-building enterprises practically do not pay any dividends because of the low profitability and unsustainable financial position that has been rapidly deteriorating in recent years.

A significant, if not main, impact on the dividend policy of domestic companies is provided by the composition of shareholders. The structure of the composition of shareholders of Russian enterprises is presented in Table 2.

Despite several stages of privatization, the state still remains one of the largest owners. In Russia, there are even special stock indices of companies with public ownership and regulated activities, which include shares of 34 leading Russian companies, a large part of which are monopolists or main players in their markets.

Being a majority or controlling shareholder, the state directly affects the dividend policy of these companies, in fact determining its parameters. At the same time, the goals of such shareholder may be very far from economic.

TABLE II. Structure of shareholders in Russian Federation

\begin{tabular}{|l|c|}
\hline \multicolumn{1}{|c|}{ Type of owner } & Share \\
\hline Authorities (incl. regional) & $20.6 \%$ \\
\hline Insiders & $37.6 \%$ \\
\hline Strategic investors & $13.5 \%$ \\
\hline Share of negotiable stocks (free float) & $28.3 \%$ \\
\hline Stock market as a whole & $100 \%$ \\
\hline
\end{tabular}

It should be noted that at the initial stages of dividend policy development in the Russian Federation, the owner, meaning the state received an extremely low level of dividend income. According to statistics, the share of dividends in the total amount of non-tax revenues at the beginning of 2005 was no more than $7 \%$. The number of joint-stock companies with a stake in the charter capital of the Russian Federation, which accrued certain dividends, has not exceeded $17 \%$ of the total number since 2001 , more than $80 \%$ of the dividend income of which was provided by only 15 joint-stock companies ${ }^{1}$.

In order to overcome these negative trends in 2005, the Ministry of Economic Development and Trade developed a draft resolution of the Government of the Russian Federation on the dividend policy of state companies. The draft presupposed annual payments of dividends equal to $10-20 \%$ of net profit. Since 2012, joint-stock companies with public ownership were supposed to allocate at least $25 \%$ of net profit for dividends without taking into account the income from revaluation of financial investments. Starting from 2015, the bar was raised to $50 \%$ because of the problems of financing the state budget.

Despite rather ambiguous results (in practice, the dividend yield of state companies in 2015-2016 ranged from 0 to $100 \%$ ), the directive intervention of the state in the dividend policy of the controlled companies will have a serious impact on the general situation in this sphere in the near future ${ }^{2}$.

The dividend policy of private Russian companies and the amount of payments allocated for these purposes also significantly depends on the composition and motives of majority shareholders that are often represented by a narrow circle of interrelated persons or by management.

Depending on the need, the owners of such companies can significantly limit dividend payments or not implement them at all. Through various manipulations (for example, through transfer prices or withdrawal of profits to subsidiaries), their official profit is understated, and the income of controlling shareholders stays in the accounts of affiliated intermediaries or in offshore accounts. At the same time, enterprises can

\footnotetext{
${ }^{1}$ Source: www.gks.ru.

${ }^{2}$ While the article was prepared, the Government of the Russian Federation was considering the project on the prolongation of increased dividends to the state-owned companies for 2017-2019.
} 
work on the verge of balance sheet losses, while their main owners are flourishing.

Russian enterprises can also pay record-high dividends if majority shareholders are interested in it. For example, in the context of the financial crisis of 2008-2009 and in the postcrisis period, majority shareholders of well-off companies actively applied the practice of calculating interim dividends that were used to repay loans or for other projects. Thus, in 2009, two large companies - TNK-BP and VimpelCom, which are co-owned by Alfa Group, decided to pay interim dividends. The group needed the funds to pay off VEB loan that was taken for refinancing the loan of Deutsche Bank. At the same time, TNK-BP allocated almost $100 \%$ of the net profit received for 9 months to the interim dividends.

Dividend payments are also often used by majority shareholders for financing other businesses that are not related to the main activity of the controlled entity.

The economic sanctions imposed by Western countries in 2014 had a significant impact on the dividend policy of Russian companies. At the same time, studies show that the results of their impact are quite controversial.

Deteriorating financial conditions, a sharp increase of the exchange rate, the interest rates and the inflation led to a decrease or a halt in dividend payments in many sectors. There are going to be a number of examples of companies that were forced to adjust their dividend policy, taking into account the tightening of creditors' claims.

On the other hand, successful companies that have adapted to the new conditions not only increased dividends, but also began to actively introduce the practice of intermediate payments (once a quarter or half a year). The main reason for this phenomenon is the presence of majority shareholders who are actively withdrawing funds from business to finance other needs or companies, which has already been analyzed. The only thing that should be noted is that as a result, in the Russian Federation in 2015 - 2016, there was a record for dividend payments, which amounted to 1.3084 and 1.224 trillion rubles, respectively. Taking into account the increased demand for dividends from the state, it can be expected that this record will be beaten in the nearest future.

The most important institutional factor, affecting the dividend policy of domestic enterprises, is legislation. It should be noted that the legal framework in this area is constantly being improved, gradually approaching the world standards and practices of developed countries. In 2014-2016, significant amendments were made to the Russian legislation, aimed at protecting the rights of shareholders, clearly defining the basis, the terms of announcing and paying dividends and the basic rights of holders of ordinary and preferred shares [1].

Summarizing the intermediate results, one should note that the considered endogenous factors have a direct effect and largely determine the content and consequences of the effects of factors of the other group, i.e. endogenous.

The most significant factors of this group are:

- $\quad$ an increase in the number and volume of operations for buy back;
- growth of the aggregate dividend yield of the Russian stock indices;

- mass companies transfer to payments of interim dividends;

- $\quad$ significant debt burden of a number of companies and individual industries, consideration of creditors' interests in dividend policy;

- complexity and intricacy of the calculation base methods, which hinders the forecast of dividends;

- dividend payments on the residual principle, the lack of a clear dividend policy for many Russian companies and, as a result, the unpredictability of decisions on dividend payments and their volumes for many Russian companies.

It is known that the payment of dividends can be carried out in various forms, each of which has its own advantages and disadvantages. The most common forms include:

- $\quad$ payments in cash (cash dividends);

- automatic dividend reinvestment plans;

- $\quad$ payment of shares (stock dividends);

- $\quad$ stock split;

- repurchase of treasury shares (stock repurchase / buy back), etc.

The main form of dividend payments that is widely used in practice throughout the world is the monetary one. At the same time, in recent years in developed countries, a certain form of payment has been widely used - the repurchase of shares, and in several countries it has become prevalent [7, 10]. As an illustration, below there are the results of a comparative analysis of the forms of dividend payments considered for US companies that are part of the well-known stock exchange index S\&P500.

TABLE III. Shares purchase and dividends of American companies for 20112015. (US \$ bln)

\begin{tabular}{|c|c|c|c|c|c|}
\hline Determinant & $\mathbf{2 0 1 5}$ & $\mathbf{2 0 1 4}$ & $\mathbf{2 0 1 3}$ & $\mathbf{2 0 1 2}$ & $\mathbf{2 0 1 1}$ \\
\hline $\begin{array}{c}\text { Aggregate } \\
\text { volume of } \\
\text { redemption }\end{array}$ & 587.07 & 579.56 & 503.53 & 399.25 & 449.30 \\
\hline $\begin{array}{c}\text { Yield of } \\
\text { redemption }\end{array}$ & $3.09 \%$ & $3.13 \%$ & $3.16 \%$ & $2.98 \%$ & $3.72 \%$ \\
\hline $\begin{array}{c}\text { Total amount of } \\
\text { dividends }\end{array}$ & 417.23 & 381.60 & 333.44 & 305.23 & 255.90 \\
\hline Dividend yield & $2.19 \%$ & $2.06 \%$ & $2.09 \%$ & $2.28 \%$ & $2.12 \%$ \\
\hline \multicolumn{7}{|c|}{ Source: Bloomberg } \\
\hline
\end{tabular}

As a result of such operations, the number of shares in circulation decreases, and earnings per share (EPS) increase. This gives an opportunity to automatically increase the amount of profit for the remaining shares and increase the dividend payout ratio in the forthcoming period. In addition, the purchase of treasury shares usually leads to an increase in their rate, which brings additional income to shareholders in the form of capital gains.

Bought out shares are called treasure stock and can be realized once again among existing or new owners, used for motivation programs of managers, reserved for the issue of 
convertible bonds or placement in foreign markets (for example, as part of ADR and GDR programs), or redeemed. ${ }^{3}$

The redemption of shares reduces excess cash and also increases financial leverage and can lead to a more efficient capital structure. Finally, it is one of the ways of protection against unfriendly takeovers.

In general, the repurchase of shares is a positive signal for the market.

Analysis shows that such policy is becoming increasingly common among domestic companies.

Large-scale programmes for redemption of treasury shares were sold by Lukoil, Surgutneftegaz, MTS, Polus Gold, Severstal, LSR, Norilsk Nickel, Uralkali and other companies. The aggregate indicators of shares redemption and dividend payments for Russian companies, included in the RTSI index for the period from 2011 to 2015, are presented below.

TABLE IV. Shares purchase and dividends of Russian companies for 20112015. (US \$ bln) ${ }^{\mathrm{a}}$

\begin{tabular}{|c|r|r|r|r|c|}
\hline Determinant & $\mathbf{2 0 1 5}$ & $\mathbf{2 0 1 4}$ & $\mathbf{2 0 1 3}$ & $\mathbf{2 0 1 2}$ & $\mathbf{2 0 1 1}$ \\
\hline $\begin{array}{c}\text { Aggregate volume } \\
\text { of redemption }\end{array}$ & 0.92 & 3.08 & 10.55 & 8.21 & 11.38 \\
\hline $\begin{array}{c}\text { Yield of } \\
\text { redemption }\end{array}$ & $0.25 \%$ & $0.77 \%$ & $1.62 \%$ & $1.21 \%$ & $1.68 \%$ \\
\hline $\begin{array}{c}\text { Total amount of } \\
\text { dividends }\end{array}$ & 62.90 & 32.42 & 25.80 & 27.46 & 15.08 \\
\hline Dividend yield & $17.25 \%$ & $8.08 \%$ & $3.95 \%$ & $4.05 \%$ & $2.22 \%$ \\
\hline \multicolumn{5}{|c|}{${ }^{\mathrm{a}}$ Source Bloomerg } \\
\hline
\end{tabular}

Despite the growth in the popularity of such transactions, in terms of their number and volumes the Russian market is significantly inferior to the markets of developed countries. At the same time, as the macroeconomic and political situation improves, the number of such transactions will increase.

As we can see from the table, in the post-crisis period there has been a rapid growth in the dividend yield of domestic indices, which significantly exceeds this figure in developed countries.

A similar trend is being observed with respect to the dividend payout ratio (PR). If in 2011, companies, whose shares are included in the MICEX index, sent only $14.3 \%$ of net profit for dividends, then in 2013, this figure amounted to $38.3 \%$.

Along with the growth in overall dividend payments, another reason for this situation is the devaluation of the ruble. Indirect confirmation of this opinion is the reduction in 2016 of the dividend payout ratio to $31.2 \%$ due to the companies' lack of surplus profits from the devaluation of the ruble.

We have already discussed the main reason for the transition of many companies to intermediate dividend payments. Other motives that should also be indicated include the desire of companies to attract additional investors,

\footnotetext{
${ }^{3}$ According to the Russian legislation, treasury stocks do not give the right to vote, they are not taken into account during the vote, there are no dividends for them and they can be included in the balance of the company for not more than a year.
}

especially institutional investors, for whom such policy is very attractive.

The main consequences of the global financial crisis of 2008 and the introduction of international sanctions are the growth of indebtedness of Russian companies and the problems of its refinancing. Together with the aggressive borrowing policy pursued by many Russian companies in the pre-crisis and post-crisis period, this led to the need for changes in the dividend policy, in order to take into account the covenants of creditors and control the level of the debt burden. This trend is most pronounced in the metallurgical industry.

Below there are examples of key parameters of dividend policy (a calculation base and an allocation coefficient) of a number of Russian companies after the revision of the policy.

TABLE V. Parameters of the dividend policy of Russian companies ${ }^{\mathrm{a}}$

\begin{tabular}{|c|l|}
\hline Company & \multicolumn{1}{|c|}{$\begin{array}{c}\text { Calculation base for the dividend payments / } \\
\text { Profit allocation coefficient }\end{array}$} \\
\hline 'Norilsk Nikel' & $\begin{array}{l}\text { It is recommended to allocate 60\% EBITDA for } \\
\text { dividends, if ratio Net debt/EBITDA for the end will } \\
\text { be less than 1.8, and 30\% EBITDA - if it is more } \\
\text { than 2.2. }\end{array}$ \\
\hline 'Severstal' & $\begin{array}{l}\text { There is the payment of quarter dividends of not less } \\
\text { than 50\% of net profit, which is calculated according } \\
\text { to IFRS in case ratio Net debt/EBITDA is less or } \\
\text { equal to 1. If ratio Net debt/EBITDA is more than 1, } \\
\text { the company will pay dividends of 25\% of net profit. }\end{array}$ \\
\hline 'NMLK' & $\begin{array}{l}\text { There is the payment of dividends on the quarter base } \\
\text { in the following range: 1) if ratio Net debt / EBITDA } \\
\text { is less or equal to 1.0, the level of dividends will be } \\
\text { within the limits - 50\% of net profit and 50\% of free } \\
\text { cash flow; 2) if ratio Net debt / EBITDA is more than } \\
1,0, \text { the level of dividends is within the limits - 30\% } \\
\text { of net profit and 30\% of free cash flow. }\end{array}$ \\
\hline 'Megafon' \\
$\begin{array}{l}\text { The company pays the bigger part to the } \\
\text { shareholders: either 50\% of net profit, or 70\% of free } \\
\text { cash flow. At the same time, the debt burden after the } \\
\text { payment of dividends should be between 1.2 and 1.5 } \\
\text { OIBDA. }\end{array}$ \\
\hline a'Source: companies' websites.
\end{tabular}

The desire of many companies to increase the flexibility of the decisions made in this sphere and to limit dividend payments led to the development of "smart" methods for calculating the dividend base, as well as to vague formulations of the possible payout ratio values, which is often specified as a range of values or with the wording "no less".

For example, a well-known Russian company, Gazprom, publishes three types of reporting: RAS (Russians Account Standard), one that is consolidated under RAS and one that is consolidated under IFRS. At the same time, in accordance with the law, RAS accounts are used when calculating dividends. The dividend policy of Gazprom implies payments of $17.5 \%$ to $35 \%$ of net profit. At the same time, the calculation of the base is made according to the following scheme: part of the net profit of $10 \%$ is directed to payment of dividends; part of the net profit of up to $75 \%$, but not less than $40 \%$ is reserved for use for investment purposes of the company; the remaining part of the net profit is channeled 
equally for the payment of dividends and reservation for use for investment purposes.

The dividend policy of a number of companies allows the use of both the RAS standard and IFRS for calculating the base. For example, in 2013, "Rostelecom" directed 25\% of RAS profit for dividends, and by the end of $2014-25 \%$ of profits under IFRS.

It is also known that the financial result of the company's activities can significantly differ; it can even be the absolute opposite one, depending on the use of one or another standard. For example, the dividend base can be significantly influenced by the results of revaluation of foreign currency assets and liabilities, etc.

Finally, many Russian companies do not have a clearly formulated dividend policy at all. It might seem like a paradox, but the best examples here are representatives of retail trade.

For example, the board of directors of a Russian distributor of different equipment - M.Video - while determining the dividend, recommended to the general meeting of shareholders, is guided by the group's net profit under IFRS. The decision on the distribution of profits is made based on such factors as the amount of net profit, indicators of financial and economic plans, the structure of working capital, debt burden.

\section{CONCLUSION}

The study showed that currently about $40 \%$ of domestic enterprises, whose shares are listed on the MICEX and RTS, do not pay dividends at all. Many of them still remain closed in terms of information and are not ready to share their income with shareholders.
Summing up the final results, it should be noted that many problems in the field of dividend policy center around corporate ethics and are not always subjected to legislative or economic regulation.

Modern features of the dividend policy of domestic companies should be taken into account in the process of making both investment and financial decisions by all the concerned parties.

\section{References}

[1] The Federal Law "On Joint-Stock Companies" of 26 December, 1995 №208 (with subsequent amendments and additions) / Consultant Plus: computer-assisted legal research system. www.consultantplus.ru

[2] J. Lintner, "Distribution of Income of Corporations among Dividends, Retained Earnings and Taxes", American Economic Review, vol. 46, pp. 97-113, 1956.

[3] M Miller, F. Modigliani, "Dividend policy, growth and the valuation of shares”, Journal of Business, vol. 34, pp. 411-433, 1961.

[4] E.F. Fama, H. Babiak, "Dividend Policy: An Empirical Analysis", Journal of the American Statistical Association, vol. 63, pp. 1132-1161, 1968.

[5] M. Miller, K. Rock, "Dividend policy under asymmetric information", Journal of Finance,vol. 40, pp. 1031-1051, april 1985.

[6] A.R.Ofer, D. Siegel, "Corporate financial policy, information and market expectations: An empirical investigation of dividends", Journal of Finance, vol. 42, pp. 889-911, april 1987.

[7] D. Scoter, E. Brigham, P. Evanson, "The Dividend Cut Heard 'Round the World': The Case of FPL", Journal of Applied Corporate Finance, vol. 9, pp. 4-15, 1996.

[8] R.D. Boehme, S.M. Sorescu, "The long-Run Performance Following Dividend Initiations and Resumptions: Underreaction or Product of Chance?", Journal of Finance, vol. 57, pp. 871-900, 2002.

[9] I. Lukasevich, "Dividend policy: theoretical aspects and peculiarities in Russia“, Corporate finance, vol. 4, pp. 228-241, april 2007.

[10] K.Chan, D Ikenberry, J. Lee, "Do Managers Time the Market? Evidence for Open-Market Share Repurchase", Journal of Banking and Finance, vol. 31, pp. 2673-2694, 2007. 